\title{
THE EFFECTS OF PARTICLES ORIENTATION ON LATERAL PRESSURE WITHIN THE CONFINED VERTICAL WALLS
}

\author{
Aleksej Aniskin, Matija Orešković, Goran Kozina
}

Preliminary communication

The effects of particles orientation, as a result of filling technology, on horizontal pressure within the confined vertical walls is investigated in this experimental study. Experimental measurements of pressure were performed in a model of cell construction with confined rigid steel walls. Filling was performed in three different ways according to predominant angle of grain orientation to the horizontal line of $0^{\circ}, 45^{\circ}$ and $90^{\circ}$. Because of different particles orientation angle, certain anisotropy of shear failure parameters and significant difference in lateral pressure occur. Experiment results showed a significant difference in horizontal pressure at different angles of particle orientation. At angle $90^{\circ}$ horizontal pressure was on average $200 \%$ more than at $0^{\circ}$

Keywords: anisotropy of shear strength; confined vertical walls; lateral pressure; particle orientation; structure model

Utjecaj orijentacije čestica na bočni tlak u omeđenim paralelnim stjenkama

Prethodno priopćenje

Provedeno je eksperimentalno istraživanje utjecaja orijentacije čestica materijala, zasipanog specijalnom tehnologijom, na horizontalni bočni tlak na paralelne vertikalne stjenke. Eksperimentalna mjerenja tlaka izvodila su se u modelu konstrukcije s ograničenim krutim čeličnim stjenkama. Zasipavanje materijala u model se izvodilo na tri različita načina tako da su dominantni kutovi orijentacije čestica u odnosu na horizontalnu liniju bili $0^{\circ}, 45^{\circ}$ i $90^{\circ}$. Zbog različitog kuta orijentacije čestica, javlja se anizotropija parametara posmične čvrstoće, pa su se bočni tlakovi pri mjerenju značajno razlikovali. Rezultati istraživanja pokazali su značajne razlike u horizontalnim tlakovima pri različitim kutovima orijentacije čestica. Pri kutu od $90^{\circ}$ horizontalni tlak bio je u prosjeku $200 \%$ više nego pri $0^{\circ}$.

Ključne riječi: anizotropija posmične čvrstoće; bočni tlak; model konstrukcije; orijentacija čestica; paralelne bliske stjenke

\section{Introduction}

Structures with confined vertical walls are very common in hydrotechnical engineering, particularly in marine ports, for example in constructions such as narrow piers, poole quay extensions, cofferdams, sheet pile cells structures, berthing and mooring dolphin structures, silos for grain storage and other.

In the calculation of these structures, it is necessary to determine the loads acting on the inner wall of the structure. For the calculation of soil pressures on confined sidewalls, the results of the Janssen's theory [1] are still applying. Basic premise of the theory was that the filling material is homogeneous and isotropic.

In reality, filling of stone or soils and particularly of dredging waste from nearby underwater quarries and marine ports approaches are extremely heterogeneous and anisotropic by natural conditions of sedimentation and lithification. In addition, both factors, heterogeneity and anisotropy largely depend on the filling technology, i.e. character and sequence of the soil mass creation $[3,4,5]$. That is why Janssen's theory needs to be developed, taking into account heterogeneity and anisotropy.

\section{Materials and methods used in the experiment 2.1 Materials}

It is well known that the mechanical properties of a discrete environment (incoherent soil), which consists of separate hard particles (grains), are mostly defined by internal friction, form and the mutual position of the particles [6]. Discrete environments are characterized by horizontal expansion caused by the indentation of the particles in interstitial spaces, i.e. pores, under vertical loading. This property mostly depends on the geometric shape of the individual grains and the texture of the layer of soil, which is the main cause of the anisotropy of the material [3].

For the filling technology to have an apparent effect, the influence of other factors, such as grain heterogeneity, needs to be reduced as much as possible. Adhering to this logic and wishing to further explore the effect of the technology it was chosen dry long-grain rice as the filling material for our model, with $\gamma=8,55 \mathrm{kN} / \mathrm{m}^{3}, w=0 \%$ and $w_{\mathrm{g}}=13,69 \%$, where $w_{\mathrm{g}}$ represents the water contents in the grain of the rice, while the surface of the rice is completely dry. The rice grains were approximately uniform in shape, with the uniformity coefficient $c_{\mathrm{u}}=$ 1,13 . The shape of the tested rice grain was very similar to that of an ellipsoid of an average size of $8 \times 2 \times 2 \mathrm{~mm}$, while the direction of the rice grains was clearly visible during the filling process (Fig. 1).

In their works Shkola et al. [3, 7, 8], Molenda [9] and Nishimura [10] define the anisotropy of soil strength parameters $c$ and $\varphi$ in relation to the texture and the predominant orientation of the grain. Let us mark $\alpha$ as the predominant orientation angle of the grain in relation to the horizontal line. Then the lateral-pressure coefficient, as a function of the strength parameters $c$ and $\varphi$, is also anisotropic. Accordingly, when using different filling methods (textures), the horizontal pressure will necessarily be different, while for the observed material (long-grain rice) it can be assumed that the horizontal pressure will increase with the increase of the predominant angle of the position of the longer grain axis $(\alpha)$ in relation to the horizontal line from $0^{\circ}$ to $90^{\circ}$ (Fig. 1). Therefore, greater pressure can be expected in situation b) than in situation a). 


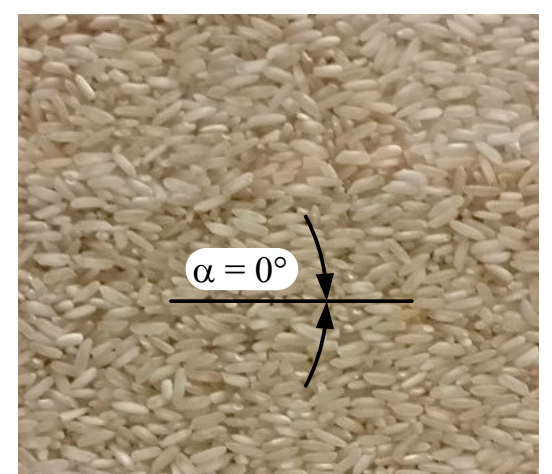

a)

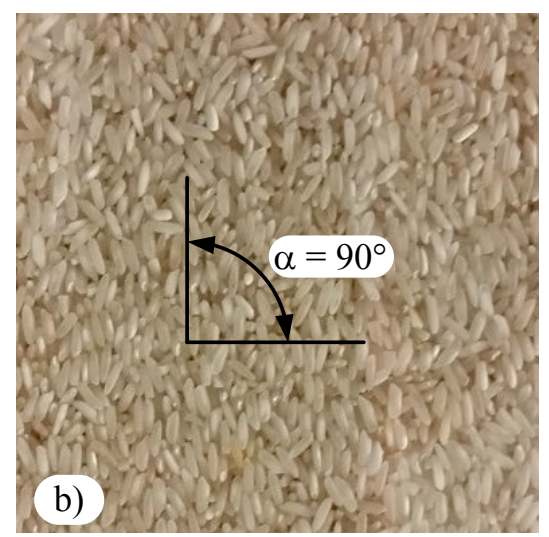

Figure 1 The predominant orientation angle of the grain in relation to the horizontal line a) $0^{\circ}$, b) $90^{\circ}$

\subsection{Experiment methods}

The authors of this article have conducted a number of original experiments on a specially designed model in order to determine the difference in horizontal pressure at various angles $\alpha$. Molenda et al. [11] describe similar experiments concerning the change of radial distribution of vertical stress at the bottom of a silo depending on the technology used to fill the silo with grain. Zhong et al. [12] describe experiments with regards to the research of the lateral expansion of iron rods with an oval cross section depending on different filling conditions.

The model is a steel cuboid whose size in plan is 0,5 $\times 0,5 \mathrm{~m}$ with a height of $1,05 \mathrm{~m}$. It has an opening on its upper part - as shown in Fig. 2. The back wall of this structure is reinforced by reinforcement ribs, which can be installed into 4 different positions - making the possible distance between the parallel walls $5,10,15$ or $50 \mathrm{~cm}$. a)

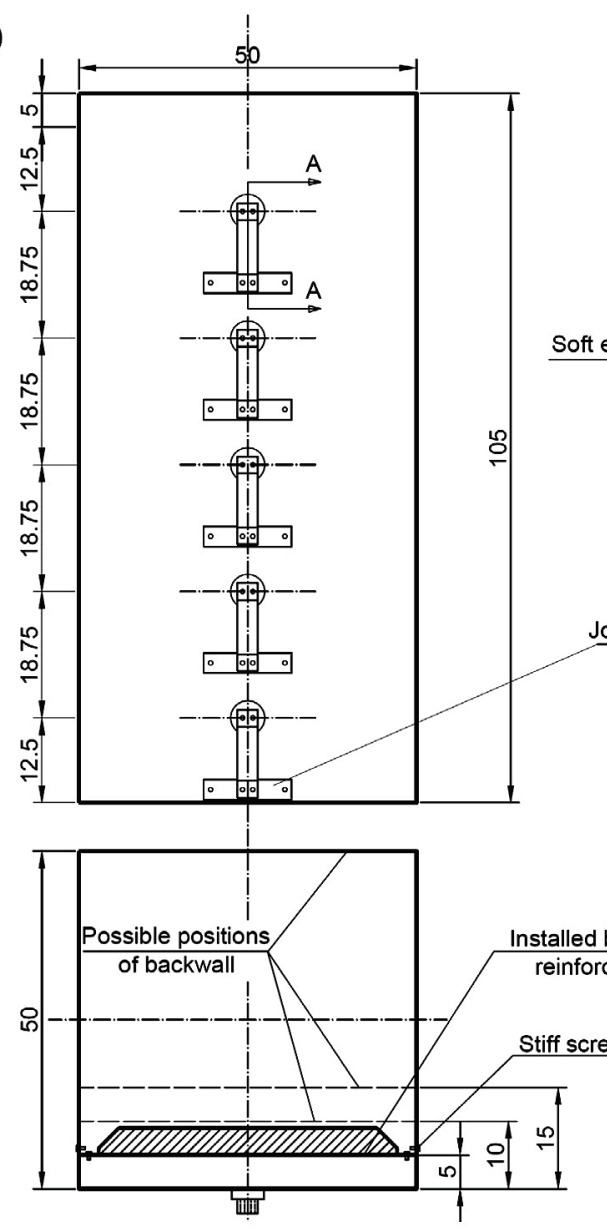

Section A-A

b) Connection details of single-point load cells on the frontal wall of the model. (magnified 5x)

Figure 2 The structure of the model with a detailed depiction of the measuring cell

In order to analyse the plain problem the distance between the walls was chosen to be $5 \mathrm{~cm}$. The crosssection ratio of wall lengths was $1: 5$, while the ratio in the vertical cross section was 1:20, which necessarily resulted in Jansen's effect of pressure saturation [1]. 
Horizontal-pressure values were measured on the axis of symmetry of the frontal wall at five measuring points (Fig. 2a) using aluminium type-6530 single point tensiometer measuring load cells manufactured by Xi'an Ruijia Measurement Instruments Co. Ltd., which have a capacity of $10 \mathrm{~kg}$, an input resistance of $406 \Omega$ with sensitivity of $2,0 \pm 0,15 \mathrm{mV} / \mathrm{V}$.

At each measuring point the load cell was fixed onto the external part of the frontal wall in its lower part, while a steel cylinder, functioning as a piston inserted in the somewhat larger opening of the frontal wall of the device (Fig. 2b), was fixed onto the upper part of the cell. The diameter of the cylinder was $48 \mathrm{~mm}$, the diameter of the opening was $50 \mathrm{~mm}$, resulting in a $1 \mathrm{~mm}$-wide radial gap between the wall of the device and the cylinder. The radial gap was covered with a flexible thin polyethylene membrane, so as to prevent particle entry.

Signals coming from the cells were read using the 8channel Quantum X device manufactured by the German company HBM. Measuring was synchronised on all five channels of device and carried out without interruption during the entire filling procedure. The tests were carried out under laboratory conditions at a temperature of $20^{\circ} \mathrm{C}$ and relative humidity of $50 \%$.

Force was measured as the output data, while both the known surface of the piston and the average normal stress on the walls of the model were also defined. Before measuring, the device was calibrated by measuring the hydrostatic water pressure. The difference between the measured and calculated water pressure values was on average $1,7 \%$.

Filling of material into the model was carried out in three various modes, depending on the predominant direction, that is, angle of the grain in relation to horizontal line $\alpha$, with the angles being $0^{\circ}, 45^{\circ}$ and $90^{\circ}$. The model was filled with material up to a height of $1 \mathrm{~m}$.

The backfill angle of $0^{\circ}$ was achieved by filling from above while the model was in a vertical position (Fig. 3a). Filling at angles of $45^{\circ}$ and $90^{\circ}$ was carried out using special technology, as shown in Fig. 3.
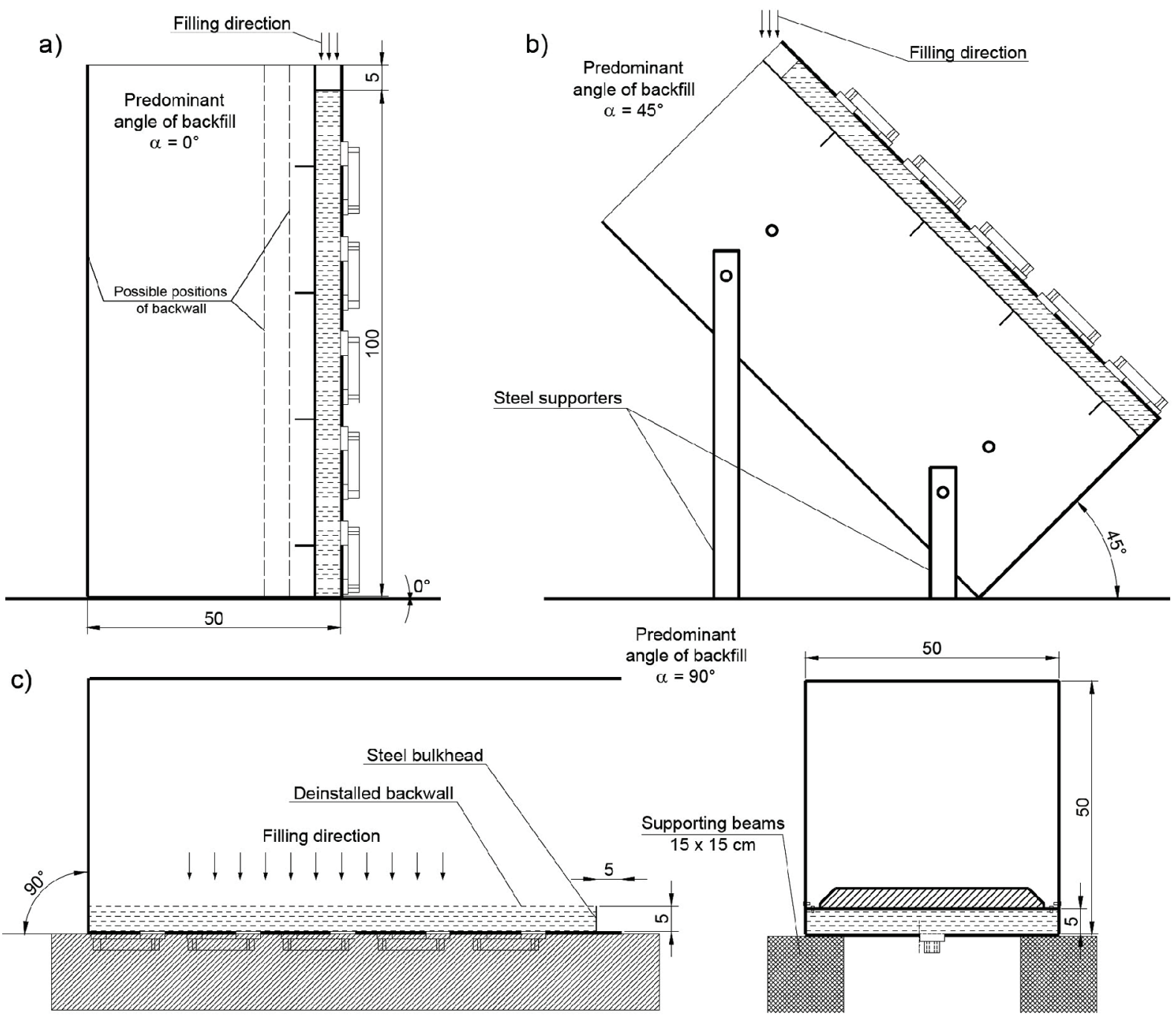

Figure 3 Technology used for filling the device, a) $0^{\circ}$, b) $45^{\circ}$, c) $90^{\circ}$

The backfill angle of $45^{\circ}$ was achieved by fixing the structure onto a horizontal platform using special steel supporters (Fig. 3b). The model was then filled vertically from above, with the falling particles mostly ending up in a horizontal position because of their geometrical shape and the pull of gravity. After the filling procedure had been completed, the structure was put back into a vertical position very slowly. Filling at an angle of $90^{\circ}$ was performed by putting the model onto two horizontally arranged beams into a horizontal position, after which the 
back wall was deinstalled and a special steel bulkhead 5 $\mathrm{cm}$ in height was inserted at a distance of $1 \mathrm{~m}$ from the bottom. After the filling process the surface was very carefully evened out, the back wall was re-installed and the model was very slowly put back into a vertical position.

So as to determine the consistency of the measured values, testing was carried out 3 times at each separate angle, with the total amount of tests being 9. Deviation in the average measured pressure values differed depending on the filling mode used - when $\alpha=0^{\circ}$, the deviation was $\pm 8,3 \%$, at $45^{\circ}$ it was $\pm 17,57 \%$ while at $90^{\circ}$ it amounted to $\pm 5,8 \%$.

Each measuring procedure was carried out according to the following sequence:

- the functionality of each individual cell was inspected while the model was in a vertical position;

- measuring was initiated at vertical position and tracked during the whole filling process;

- the model was evenly and gradually filled with material without any sudden action;

- $\quad$ after the filling process the model was very carefully returned into a vertical position;

- a pause of usually 5 to 10 min was introduced so as to wait for the measured values to stabilize;

- $\quad$ the values were measured.

\section{Results and discussion}

The results of the measuring are shown in the graphic diagram in Fig. 4 - the abscissa represents the normal pressure values in $\mathrm{kN} / \mathrm{m}^{2}$, while the ordinate shows the relative depth $z / H$.

As expected, due to the anisotropy of the material at different filling conditions, different horizontal pressure values are obtained - when the backfill angle was $90^{\circ}$ pressure values was on average 3 times higher than the pressures at an angle $0^{\circ}$. When during filling $\alpha=0^{\circ}$, the measured data fits very well into Janssen's theory (Fig. 4, Curve 1) and can be compared to the data of prominent authors, such as Reimbert et al. [13], Schulze [14], Brown et al. [15] and others.

The horizontal pressure values at a backfill angle of $45^{\circ}$ (Fig. 4, Curve 2) are greater than at $0^{\circ}$ on average by $90 \%$ up to approximately 0,6 of the model's depth. They decrease towards the bottom and are by $40 \%$ smaller in the remaining part, which can be explained by the solid bottom, whose effect is most prominent when $\alpha=45^{\circ}$. In terms of its characteristics Curve 3 is more similar to Curve 1, while the pressure co-values are on average 200 $\%$ greater -the maximum level being clearly evident and achieved at half depth. When there are insignificant variations in the bulk density of the filling (approximately $\pm 8 \%$ ), the lateral pressure differs greatly, which points to the change in the lateral-pressure coefficient $k=\sigma_{3} / \sigma_{1}$, whereas its value rises with the increase of angle $\alpha$. Molenda et al. [12] and Tong et al. [13] have established similar tendencies in lateral coefficient change.

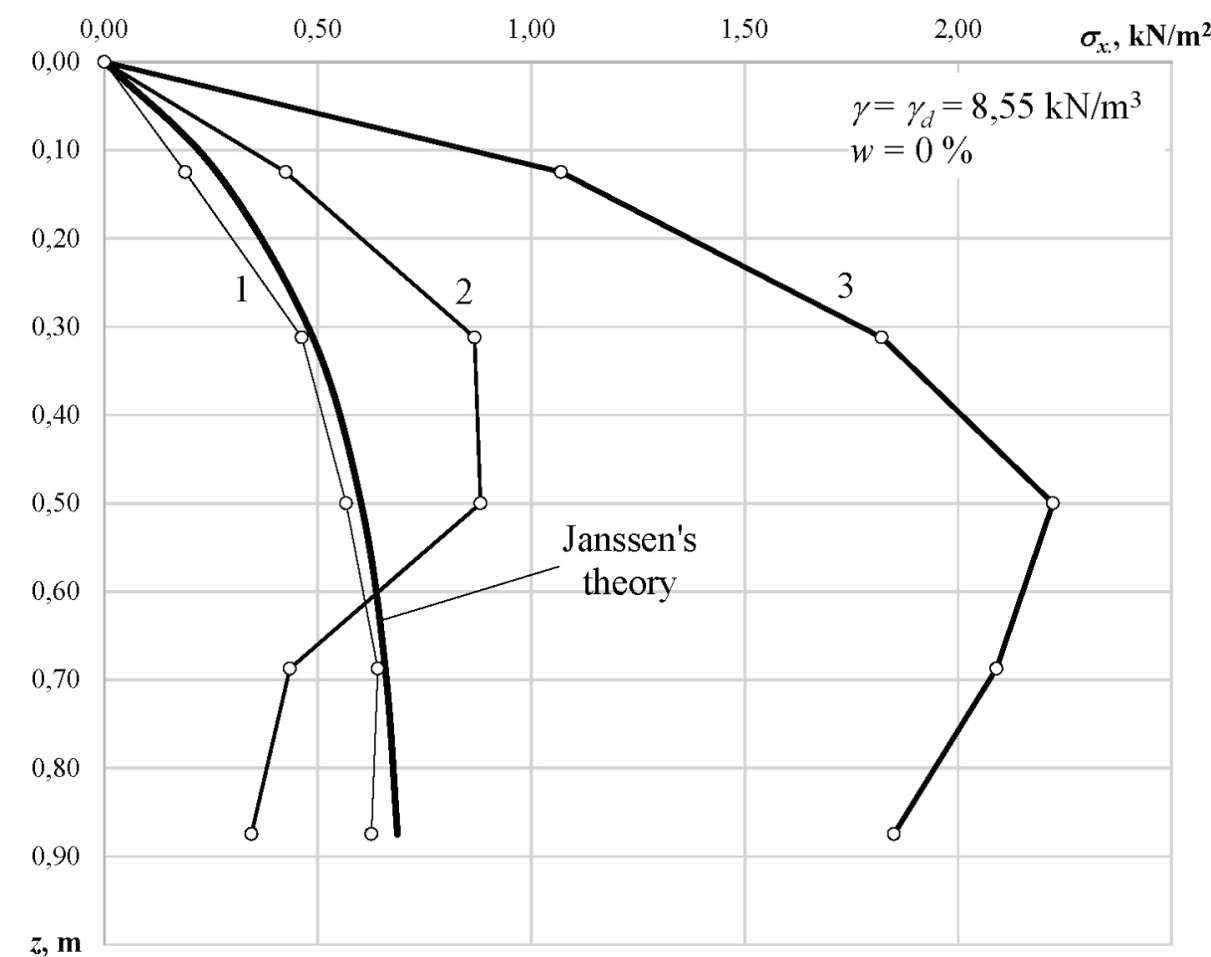

Figure 4 Diagrams of measured horizontal pressure values when using different filling technologies, $1 \div 0^{\circ}, 2 \div 45^{\circ}, 3 \div 90^{\circ}$

At each testing the weight and volume of the material was measured, as well as the bulk density. Tab. 1 shows the co-measured values and the calculated void ratio at each individual filling. The data from the table suggests that the most compact sample of material is achieved at a backfill angle of $90^{\circ}$, while the most porous sample at a position of $45^{\circ}$. 
Table 1 The physical characteristics of rice at various backfill angles

\begin{tabular}{|c|c|c|c|c|}
\hline $\begin{array}{l}\text { Number of } \\
\text { experiment }\end{array}$ & $\begin{array}{c}\text { Grain } \\
\text { angle, } \alpha\left(^{\circ}\right)\end{array}$ & $\begin{array}{c}\gamma=\gamma_{\mathrm{d}} \\
\left(\mathrm{kN} / \mathrm{m}^{3}\right)\end{array}$ & $\gamma_{\mathrm{s}}\left(\mathrm{kN} / \mathrm{m}^{3}\right)$ & $e,[1]$ \\
\hline 1 & \multirow{3}{*}{$0^{\circ}$} & 8,74 & 13,46 & 0,54 \\
\hline 2 & & 8,58 & 13,46 & 0,57 \\
\hline 3 & & 8,71 & 13,46 & 0,55 \\
\hline Avg. & & 8,68 & 13,46 & 0,55 \\
\hline 1 & \multirow{3}{*}{$45^{\circ}$} & 7,88 & 13,46 & 0,71 \\
\hline 2 & & 7,74 & 13,46 & 0,74 \\
\hline 3 & & 7,84 & 13,46 & 0,72 \\
\hline Avg. & & 7,82 & 13,46 & 0,72 \\
\hline 1 & \multirow{3}{*}{$90^{\circ}$} & 9,07 & 13,46 & 0,48 \\
\hline 2 & & 9,32 & 13,46 & 0,44 \\
\hline 3 & & 9,09 & 13,46 & 0,48 \\
\hline Avg. & & 9,16 & 13,46 & 0,47 \\
\hline
\end{tabular}

\section{Conclusion}

The following conclusions can be made on the basis of the conducted experimental tests:

1) The horizontal pressure differs greatly at different angles of backfilling of the rice grains.

2) There is a relation between the geometric shape of the grains and the horizontal expansion achieved by the indentation of the particles in interstitial spaces, which is manifested in the significant rise of horizontal pressure.

3) A curved line characterizes all of the diagrams of horizontal pressure.

4) When the filling process is conducted at an angle of $0^{\circ}$, the measured pressure values fit very well into the theoretical pressure from Janssen's theory.

5) When the filling process is conducted at an angle of $45^{\circ}$, the pressure is on average greater by $90 \%$ up to 0,6 of the depth, while in the remaining part it is smaller by $40 \%$.

6) 6. The mean difference in horizontal-pressure values at backfill angles of $0^{\circ}$ and $90^{\circ}$ is $200 \%$.

This experimental study shows that the filling technology can greatly influence horizontal pressure values, which is of great significance for the construction of such structures and other supporting structures, which make use of backfilling procedures. Accordingly, the technology and method of material backfilling should be analysed and used to one's advantage, meaning reducing loading of the supporting structures by using optimal filling technology.

\section{References}

[1] Janssen, H. A. Getreidedruck in Silozellen // Z. Ver. Dt. Ing. 39, (1895), pp. 1045-1049.

[2] Terzaghi, K. Theoretical Soil Mechanics. John Wiley and Sons, New York, 1943. https://doi.org/10.1002/9780470172766

[3] Shkola, A. V. Bokovoe davlenie anizotropnih gruntov na sooruzhenia. MAG VT, Odessa, 2012.

[4] Molenda, M.; Horabik, J.; Ross, I. J. Loads in model grain bins as affected by filling methods. // Proceedings of American Society of Agricultural Engineers. 36, 3(1993), pp. 915-919. https://doi.org/10.13031/2013.28416

[5] Shkola, A. V.; Aniskin, A.; Soldo, B. Osnovnie pretposilki reshenia zadachi ucheta anizotropii pri opredelenii davlenia sypuchih sred na blizkoraspolozhennye steny. // Visnyk ODABA. 48, 2(2012), pp. 258-261.

[6] Gyachev, L. V. Osnovy teorii bunkerov i silosov. Altayski politehnicheski institute, Barnaul, 1986.

[7] Shkola, A. V.; Aniskin, A. Vzaimodestvie otboynoshvartovyh palov $\mathrm{s}$ anizotropnoi gruntovoi sredoi. // Zbirnyk naukovyh prac', Seria: Gakuzeve mashinobuduvannia, budivnytstvo. 4(39), Tom 2 (2013), Poltava, pp. 302-305.

[8] Shkola, A. V.; Aniskin, A. Vliyanie tehnologii na svoistva grunta obratnyh zasipok prichalov. // Proceedings of Int. conf. on Sovremennye geotehnologii $\mathrm{v}$ stroitelstve $\mathrm{i}$ ih nauchno-tehnicheskoe soprovozhdenie, chast I., Sankt Peterburg, 2014, pp. 243-248.

[9] Molenda, M.; Stasiak, M. Anizotropia kąta tarcia wewnętrznego ziarna pszenicy. Inżynieria Rolnicza. 2(2001), pp. 245-251.

[10] Nishimura, S. Laboratory study of anisotropy of natural London Clay, PhD diss. Imperial College, London, 2005.

[11] Molenda, M.; Horabik, J.; Ross, I. J. Effect of Filling Method on Load Distribution in Model Grain Bins. // Transaction of American Society of Agricultural Engineers. 39, 1(1996), pp. 219-224. https://doi.org/10.13031/2013.27501

[12] Tong, Z.; Zhang, L.; Zhou, M. DEM Simulation of Biaxial Compression Experiments of Inherently Anisotropic Granular Materials and the Boundary Effects. // Journal of Applied Mathematics, Hindawi. 2013, (2013), pp. 1-13. https://doi.org/10.1155/2013/394372

[13] Reimbert M.; Reimbert A. Silos-Theory and Practice. Trans. TechPublication, Claustal, Germany, 1976.

[14] Schulze, D. Untersuchungen zur gegenseitigen Beeinflussung von Silo und Austragorgan, Dissertation. Fakultät für Maschinenbau und Elektrotechnik der Technischen Universität Carolo-Wilhelmina zu Braunschweig, 1991.

[15] Brown, C. J.; Lahlouh, E. H.; Rotter, J. M. Experimetns on a square planform steel silo. // Chemical Engineering Science. 55, (2000), pp. 4399-4413. https://doi.org/10.1016/S0009-2509(99)00574-6

\section{Authors' addresses}

\author{
Aleksej Aniskin, mag. ing. geoing., Senior Lecturer \\ University North \\ 104. brigade 3, 42000 Varaždin, Croatia \\ aaniskin@unin.hr
}

\author{
Matija Orešković, PhD, Eng. Sci., Senior Lecturer \\ University North \\ 104. brigade 3, 42000 Varaždin, Croatia \\ moreskovic@unin.hr
}

Dr. sc. Goran Kozina, Associate Professor University North 104. brigade 3, 42000 Varaždin, Croatia gkozina@unin.hr 